\title{
ПЕДАГОГИКА
}

УДК: 371.391

DOI: $10.24044 / \mathrm{sph} .2017 .1 .13$

ПРОФЕССИОНАЛИЗМ ПРЕПОДАВАТЕЛЯ

В УСЛОВИЯХ ПЕРЕПОДГОТОВКИ

И ПОВЫШЕНИЯ КВАЛИФИКАЦИИ ПЕДАГОГИЧЕСКИХ КАДРОВ

Д. И. Рузиева

Доктор педагогических наук, профессор

Ташкентский государственньй

педагогический университет

имени Низами

2. Ташкент, Узбекистан

\section{PROFESSIONALISM OF THE TEACHER IN THE CONDITIONS OF RETRAINING AND IMPROVING THE QUALIFICATION OF PEDAGOGICAL STAFF}

D. I. Ruzieva

\author{
Doctor of Pedagogical Sciences, professor \\ Tashkent State Pedagogical University \\ name after Nizami \\ Tashkent, Uzbekistan
}

Abstract. The article is devoted to the most important problem of our time, associated with the process of retraining and advanced training of teachers. It lists the principles in the activities of branch centers for retraining and professional development of teachers. Named the main components for the efficient operation training system, which directly affects the development of teachers' professionalism. In addition, notes the main provisions affected the progressive development of science teaching in the past more than two decades, and it is said about finding and improving the quality of educational services designed to meet the demands of modern approaches to the professional development of teachers.

Keywords: teacher; school; system of retraining and advanced training of teachers; principle; process training.

Специфика у учебно-воспитательного процесса в условиях обновления содержания вузовского образования требует от педагога непрерывного совершенствования своей квалификации, постоянного пополнения знаний и осмысления новых явлений, происходящих в повседневной жизни. В этих условиях возникает потребность развития самообразовательной, то есть индивидуальной деятельности педагога. 
Совершенствование профессионального мастерства преподавателя возможно лишь при условии непрерывного общего образования и развития личности, а не только удовлетворения узкопрофессиональных потребностей.

Решение приоритетных направлений обновления содержания образования учитывается и при планировании обучения преподавателей в отраслевых центрах переподготовки и повышения квалификации педагогических кадров.

Их главная цель - подготовить педагогов к переходу на новую систему обучения, направить их к дальнейшему творческому и духовному росту, а также регулярному самообразованию. Профессионализм и личностный рост проявляется и в участии педагогов в конференциях, семинарах, проектах, мастер-классах, творческих отчетах и т. д. И этот фактор повышения профессионализма педагога, в так называемом нами, межкурсовом периоде, то есть между обучением на курсах переподготовки и повышения квалификации также учитывается в деятельности таких центров.

Теоретической основой при организации мероприятий переподготовки и повышения квалификации педагогов являются принципы, тесно связанные между собой. К ним относятся философские, методологические, дидактико-методические и организационно-педагогические.

Одним из наиболее эффективных принципов является принцип omкрыттости. Это свойство любой педа- гогической системы, характеризующейся постоянным информационным обменом с окружающей социальной средой, при этом эффективность функционирования системы обусловлена степенью ее открытости.

Гуманизация предполагает создание комфортных условий получения непрерывного образования, при котором осуществляется совместное творчество обучаемых и обучающихся (субъект-субъектное взаимодействие) в режиме взаимного обучения, взаимообогащения и эмоционального положительного общения.

Интеграциия - один из важных принципов, лежащих в технологии отбора содержания образования. Можно выделить следующие основания интеграции знаний: онтологическое (единство мира), гносеологическое (единство человеческого сознания и законов мышления), методологическое (наличие общенаучных методов исследования), социальное (целостность человека) и др.

Интеграция знаний в педагогической науке и в образовании выступает одним из способов повышения гибкости, мобильности науки и содержания образования в условиях непрерывно меняющегося окружающего мира и знаний о нём. Возьмем принцип дифференциации, который диалектически противоположен интеграции. В педагогической науке тенденция дифференциации проявляется, в первую очередь, в увеличении научных отраслей, научных направлений и научных дисциплин. 
Принщип системности обеспечивает системную организацию непрерывного образования на основе всех его компонентов: цели, задач, содержания, методов, форм, педагогических технологий, средств обучения и различных видов учебной деятельности.

Принции региональности предполагает учёт в системе непрерывного образования определенного территориального компонента: национальных и культурных традиций, природных и социальноэкономических условий, использование в содержании образования информации, характерной для данного региона, организацию образовательного процесса, включающего лучшие традиции общечеловеческой и национальной культуры.

Принщип непрерывности вытекает из постепенности и этапности становления и развития интеллектуальной и научно-исследовательской культуры. Он предполагает организацию обучения, воспитания и развития подрастающего поколения на всех этапах: семейном, дошкольном, школьном, профессиональном, вузовском и последипломном образовании.

На каждом из данных этапов доминирует одна/две составляющих образования: обучение, воспитание, развитие.

Принцип демократизащии и всеобщности имеет два очень важных аспекта. С одной стороны, этот принцип предполагает доступность и многообразие содержания, методов и форм его представления лю- дям различного возраста в виде образовательных услуг любого вида, любого уровня в зависимости от потребностей, интересов и возможностей человека.

\section{Приницип}

предполагает

преемственности педагогических особенностей восприятия изучаемого материала, использование адекватных методов и форм обучения, воспитания и развития, отбор содержания, обеспечивающего целостное, системное восприятие закономерностей, тенденций и проблем окружающего мира.

Принции гибкости, альтернативности и вариативности образования предполагает разнообразие образовательных программ (вариативных и альтернативных), различной степени углубления и изучения экологии, специализации и профилизации, способность коррекции их содержания, выбор темпа и сроков обучения и т. д.

Таким образом, процесс повышения квалификации в образовательном пространстве республики носит системный, научнометодический характер, мобильно реагирующий на постоянно меняющиеся условия, что реализуется через: оперативное повышение квалификации; постоянную диагностику профессиональных потребностей педагогов и как результат - обновление содержания курсовой подготовки, а также технологизацию учебного процесса. Если рассматривать образование не как «потребляющий» компонент общества, а как основу благосостояния страны, 
можно считать его технологией построения будущего.

Для эффективной деятельности системы повышения квалификации в деле развития профессионализма педагогов необходимы:

* благоприятные и комфортные условия, складывающиеся из положительных взаимоотношений между членами коллектива;

* признание значимости системы переподготовки и повышения квалификации в системе вузовского образования;

* средства стимулирования добросовестного отношения педагогов к должностным обязанностям (моральное, материальное);

* создание социальных условий для самореализации и творчества педагогов;

* поощрение увлеченности педагогических кадров инновациями в сфере образования;

* ответственность за своевременное получение запланированного результата;

* социальное партнерство и поддержка системы переподготовки и повышения квалификации государственными и неправительственными организациями.
Прогрессивное развитие педагогической науки на протяэсении последних более двух десятков лет показало, что только на основе

* научного анализа,

* осмысления своего профессионального опыта,

* применения необходимой информации,

* связи теории с практикой можно добиться положительных результатов в повышении профессионального роста преподавателей вузов.

Вместе с тем на сегодняшний день предстоит еще поиск и совершенствование качества образовательных услуг, чтобы отвечать запросам современных подходов к профессиональному развитию педагогических кадров.

\section{Библиографический список}

1. Тесленко А. Н. Социализация молодежи: педагогика отношений в социуме. - А. : АГУ, 2007. - 241 с.

\section{Bibliograficheskij spisok}

1. Teslenko A. N. Socializacija molodezhi: pedagogika otnoshenij v sociume. - A. : AGU, 2007. - $241 \mathrm{~s}$.

(с) Рузиева Д. И., 2017. 